\title{
Original Paper \\ Bryophyte flora of the Apodi Plateau, Ceará, Brazil
}

\author{
Hermeson Cassiano de Oliveira ${ }^{1,3,4}$, Aline Matos de Souza ${ }^{2}$ \& Emilia de Brito Valente ${ }^{2}$
}

\begin{abstract}
In the state of Ceará, bryophytes have been mainly sampled in humid and sub-humid enclaves, remnants of Atlantic rain forest, while studies in the Caatinga Domain are practically non-existent. The present work aimed to survey the floristic composition of bryophytes of the Apodi Plateau, a region predominantly covered by Caatinga. Collections were conducted as part of the field activities of the Program for Research in the Biodiversity of the Semiarid region of Brazil (PPBio). The briological material was collected in 2014, in the Apodi Plateau located within the territory of Ceará state. Fifty-nine bryophyte species were found: 27 liverworts - Marchantiophyta - distributed in seven families and 11 genera, and 32 mosses - Bryophyta - distributed in 14 families and 26 genera. Among the species found, 25 were new records for the state of Ceará and Riccia subplana is reported for the first time for the Northeast region of Brazil. Twenty-three are new records for the Caatinga Domain. Taxonomic comments are provided for the new records for the state of Ceará and for Caatinga, as well as an illustration of the species Weisiopsis bahiensis.
\end{abstract}

Key words: Bryophyta, Marchantiophyta, taxonomy.

\section{Resumo}

No estado do Ceará, as principais áreas amostradas com relação às briófitas são constituídas de encraves úmidos e subúmidos, remanescentes da Mata Atlântica. Estudos em áreas de Caatinga são praticamente inexistentes. O presente trabalho objetivou realizar um inventário florístico das briófitas da Chapada do Apodi, dentro dos limites do território do estado do Ceará, uma região com predominância do Domínio Caatinga. As coletas fizeram parte das atividades de campo do Programa de Pesquisa em Biodiversidade do Semiárido (PPBio). O material briológico foi coletado em 2014, na área da Chapada do Apodi localizada dentro do território do estado do Ceará. Foram encontradas 59 espécies de briófitas sendo 27 hepáticas - Marchantiophyta distribuídas em sete famílias e 11 gêneros e 32 espécies de musgos - Bryophyta - distribuídas em 14 famílias e 26 gêneros. Das espécies encontradas, 25 se configuram como novos registros para o estado do Ceará e Riccia subplana está sendo citada pela primeira vez para a Região Nordeste. Estão sendo acrescentados ainda 23 novas ocorrências para a Caatinga. São fornecidos comentários taxonômicos para as novas ocorrências para o estado do Ceará e para a Caatinga. A espécie Weisiopsis bahiensis é ilustrada.

Palavras-chave: Bryophyta, Marchantiophyta, taxonomia.

\section{Introduction}

The northeastern region of Brazil occupies an area of 1,540,827 $\mathrm{km}^{2}$ (Nimer 1989), and has a semiarid climate in approximately $800,000 \mathrm{~km}^{2}$, corresponding to $10 \%$ of the Brazilian territory (Ab'Sáber 1974). The relief has altitudes mostly below $500 \mathrm{~m}$, among surfaces that reach $1,000 \mathrm{~m}$ in the Borborema, Araripe and Ibiapaba plateaus, up to $1,200 \mathrm{~m}$ in the Diamantina plateau. This altitudinal variation associated with the position in the relief, where the increasing altitude causes forced convective rains and lower temperatures, leads to the occurrence of different types of vegetation. The xerophilous Caatinga vegetation is dominant in the semiarid area, presenting physiognomic and floristic variations (Romariz

\footnotetext{
'Universidade Estadual do Piauí, Campus Heróis do Jenipapo, Av. Sto. Antônio s/n, 64280-000, Campo Maior, PI, Brasil.

${ }^{2}$ Universidade Estadual de Feira de Santana, Av. Transnordestina s/n, Novo Horizonte, 44036-900, Feira de Santana, BA, Brasil.

${ }^{3}$ ORCID: < https://orcid.org/0000-0002-1611-9562>

${ }^{4}$ Author for correspondence: hermeson123@gmail.com
} 
1974; Ferri 1980; Andrade-Lima 1981; Sampaio 1995; Rizzini 1997).

The different physiognomies of the Caatinga hold a diversified biological heritage, with rare and endemic taxa (Giulietti et al. 2004) and an invaluable richness of plant and animal species (MMA 2004). In contrast to other semiarid regions of the world, the biological diversity of the Caatinga is extremely significant (Luetzelburg 1974; Andrade-Lima 1981; Araújo Filho \& Carvalho 1997) and adds biological and economic value to Brazil. Despite such remarkable characteristics, the Caatinga is one of the least known domains in the country. This situation is a consequence of the belief that the Domain has a very low diversity, no endemic species, and vegetation that is strongly modified by anthropic actions (Giulietti et al. 2004). It is noteworthy that this vegetation is one of the most affected by human interference in Brazil; in 2008, approximately $45 \%$ of its original coverage had already been deforested (MMA 2010). According to Castelletti et al. (2004), the last intact native vegetation remnants are extremely fragmented.

The Northeast region of Brazil ranks third in number of bryophyte species, behind the South and Southeast regions (Costa \& Peralta 2015). As for the bryophyte flora of the state of Ceará, this is still partially known. Most studies on the flora of Ceará have focused on flowering plants, for they represent the predominant vegetation. There are still few reports of bryophytes in Ceará, especially due to the lack of collections in native vegetation, although bryophytes can be found even in the most inhospitable places (Brito \& Pôrto 2000). The best explored areas to date are quite small and, considering the extension of the state, it is unlikely that the results obtained portray the real situation of the bryophyte flora of Ceará. The main areas sampled until present are humid and sub-humid enclaves, remnants of Atlantic rain forest (Oliveira \& Alves 2007; Oliveira \& Bastos 2009, 2010a, b; Siqueira et al. 2011).

There are no works specifically addressing the bryophytes growing in the Caatinga in Ceará. The few studies carried out so far were floristic surveys in humid environments, in high altitudes such as the Ibiapaba Plateau (Oliveira \& Bastos 2009, 2010a,b) and the Guaramiranga mountain (Yano \& Pôrto 2006). In this context, the Apodi Plateau, located in the eastern side of Ceará, represents a relevant area to the study of bryophytes growing in the Caatinga, taking into account the lack of works in the region. The knowledge of the bryophyte flora of the Apodi Plateau is fundamental to understand the diversity of the ecosystem as a whole, aiming at environmental valuation and support to appropriate management measures.

The present study aimed to carry out a floristic survey of the bryophytes of the Apodi Plateau, within the limits of the territory of the state of Ceará.

\section{Material and Methods}

Study area

The Apodi Plateau is located in the eastern side of the state of Ceará, also extending into the territory of Rio Grande do Norte (Fig. 1). In general, the natural vegetation is represented by hyperoxerophilic Caatinga, which is part of the dominant landscape of the ecosystem of the Apodi Plateau, associated to secondary forests with varied herbaceous strata. According to Filho et al. (2001), different types of vegetation coverage can be observed in the region: Savanna (Cerrado); Forested savanna (Cerradão), currently named as xeromorphic tropical subcaducifolia forest; Carrasco; and a seasonal dense Ombrophilous Forest remnant, probably resulting from great environmental heterogeneity throughout many geological periods (Giulietti et al. 2004). Fernandes (1990) believes that the presence of a forest such as Cerradão in the state of Ceará was driven by climate change through geological time, which also caused progressions and regressions of this forest into the central region of Brazil. The predominant climate of the region is Hot Sub-humid Tropical, the soil is Yellow Dystrophic Latosol, and the mean annual precipitation and temperature is $1,061 \mathrm{~mm}$ and $25^{\circ} \mathrm{C}$, respectively.

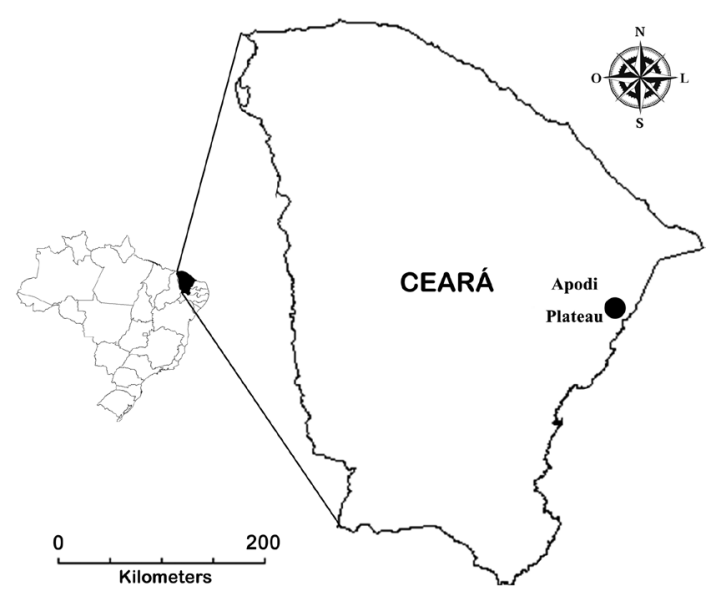

Figure 1 - Location of the Apodi Plateau. 
Collections of botanical material

Collections were part of the field activities of the Program for Research in the Biodiversity of the Semiarid region of Brazil (PPBio). Briological material was collected in 2014, in the Apodi Plateau located within the territory of Ceará, according to specialized techniques described in Frahm (2003). The material was collected manually or with the aid of a knife and stored in Kraft paper bags. In the field, altitudes and geographical coordinates were recorded at all points of collection with the aid of a GPS. The following data were also recorded: date and site of collection, type of ecosystem, habit, growth form, colonized substrate (bryocenological group), and other relevant ecological and/or taxonomic observations.

Samples were identified in the Plant Taxonomy Laboratory of the Universidade Estadual de Feira de Santana. For the macro and microscopic analysis, morpho-anatomical characteristics of gametophytes and sporophytes were observed with the aid of a stereomicroscope and an optical microscope. The classification system used was the one of Crandall-Stotler et al. (2009) for liverworts, and Goffinet et al. (2009) for mosses. The geographical distribution of the species in Brazil was based on the BFG (2018). In order to identify species, the following works were used: Buck (1998), Bordin \& Yano (2013), Costa (2016), Frahm (1991), Gradstein \& Costa (2003), Lemos-Michel (2001), Sharp et al. (1994), Yano \& Peralta (2007) and Zander (1993).

Vouchers of the identified material were deposited in the collection of the Herbarium of the Universidade Estadual de Feira de Santana (HUEFS).

\section{Results}

Fifty-nine bryophyte species were recorded, consisting of 27 liverworts - Marchantiophyta distributed in seven families and 11 genera, and 32 mosses - Bryophyta - distributed in 14 families and 26 genera (Tab. 1). Among the species found, 25 are new records for Ceará, and Riccia subplana Steph. is reported for the first time to the Northeast region of Brazil. Twenty-one are new occurrences for the Caatinga Domain.

The predominant community, regarding the colonized substrate, was the corticolous (32 spp.), followed by rupicolous (12 spp.), terrestrial (10 spp.) and epixylous (6 spp.).

A list of all the new records for the state of Ceará, for the Caatinga, and for the Northeast region, with taxonomic comments for each species, is provided in the list below, in alphabetical order of families. An illustration of Weisiopsis bahiensis (Müll. Hal.) Broth. is provided because this is a species with restricted distribution in Brazil, cited only for the states of Bahia (site where the type was collected) and Piauí, and because there are few illustrations of the species available in the literature.

\section{Marchantiophyta}

Cephaloziellaceae Douin

Cylindrocolea rhizantha (Mont.) R.M.Schust., New Hedwigia 22 (1-2): 175. 1971 [1972].

The illustrations of this species is in Gradstein \& Costa (2003).

It is characterized by bilobed leaves with acute to obtuse apex and subquadratic cells. It resembles Cylidrocolea planifolia, but presents relatively larger gametophytes $(0.5-1 \mathrm{~mm}$ long). It was found on live bark. It is a new record for the Caatinga Domain and for the state of Ceará. Brazilian geographical distribution: North (AC), Northeast (BA, PE), Midwest (GO), Southeast (ES, RJ, SP).

\section{Lejeuneaceae Cavers}

Archilejeunea fuscescens (Hampe ex Lehm.) Fulford, The Bryologist 45: 174. 1942.

The illustrations of this species is in Gradstein \& Costa (2003).

It is characterized by creeping habit, green to brown coloration, entire and imbricate underleaves, oblong-orbicular leaves with rectangular lobules, which have an apical tooth consisting of 1-2 cells. It was collected on rotting log. It is one of the most common epiphytic liverworts in the Amazon forest and is reported here for the first time for the Caatinga Domain and for the state of Ceará. Brazilian geographical distribution: North (AC, AM, PA, RR), Northeast (AL, BA, PE), Southeast (ES, MG, RJ).

Ceratolejeunea cornuta (Lindenb.) Steph., Pflanzenw. Ost-Afrikas C: 65, 1895.

The illustrations of this species is in Dauphin (2003).

It is distinguished by inflated, spherical lobules present in some parts or in the whole plant, and perianths with four horns. It was found on live bark. This is the first record for the Caatinga Domain. Brazilian geographical distribution: 
Table 1 - Bryophyte species found in the Apodi Plateau, Ceará, Brazil. Substrates (Sub.): $\mathrm{CO}=$ corticolous; $\mathrm{EX}=$ epixylous; $\mathrm{EF}=$ epiphyllous; $\mathrm{RU}=$ rupicolous; $\mathrm{TE}=$ terrestrial. Domains: $\mathrm{AM}=\mathrm{Amazon} ; \mathrm{AT}=\mathrm{Atlantic}$ rain forest; $\mathrm{SA}=$ Savannah; $\mathrm{CA}=$ Caatinga; $\mathrm{PA}=$ Pampa; $\mathrm{PL}=$ Pantanal. The number of genera and species is given inside parentheses, next to each family name. " $=$ new record for the Caatinga Domain; * = new record for the state of Ceará; $* *=$ new record for the Northeast of Brazil.

\begin{tabular}{|c|c|c|c|c|}
\hline Taxa & Sub. & Domains & World Distribution & Vouchers \\
\hline \multicolumn{5}{|l|}{ Marchantiophyta } \\
\hline \multicolumn{5}{|l|}{ Cephaloziellaceae Douin (1/1) } \\
\hline${ }^{* *}$ Cylindrocolea rhizantha (Mont.) R.M.Schust. & $\mathrm{CO}$ & AM, AT, SA & Neotropical & Reis TR 410 \\
\hline \multicolumn{5}{|l|}{ Corsiniaceae Engl. (1/1) } \\
\hline Cronisia weddellii (Mont.) Grolle & $\mathrm{TE}$ & AT, CA, SA & Endemic to Brazil & Reis TR 357 \\
\hline \multicolumn{5}{|l|}{ Frullaniaceae Lorch. (1/3) } \\
\hline Frullania caulisequa (Nees) Nees & RU & $\begin{array}{l}\text { AM, AT, CA, } \\
\text { SA, PA }\end{array}$ & Neotropical & Reis TR 404 \\
\hline Frullania ericoides (Nees) Mont. & $\mathrm{CO}$ & $\begin{array}{l}\text { AM, AT, CA, } \\
\text { SA, PA, PL }\end{array}$ & Neotropical & Reis TR 375 \\
\hline Frullania kunzei (Lehm. \& Lindenb.) Lehm. \& Lindenb. & RU & $\begin{array}{l}\text { AM, AT, CA, } \\
\text { SA, PL }\end{array}$ & Neotropical & Reis TR 404 \\
\hline \multicolumn{5}{|l|}{ Lejeuneaceae Cas.-Gil (5/12) } \\
\hline **Archilejeunea fuscescens (Hampe ex Lehm.) Fulford & EX & AM, AT & Neotropical & Reis TR 396 \\
\hline "Ceratolejeunea cornuta (Lindenb.) Steph. & $\mathrm{CO}$ & $\mathrm{AM}, \mathrm{AT}$ & Neotropical & Reis TR 399 \\
\hline "*Ceratolejeunea laetefusca (Austin) R.M.Schust. & $\mathrm{CO}$ & $\mathrm{AM}, \mathrm{AT}, \mathrm{SA}$ & Neotropical & Reis TR 381 \\
\hline "*Cheilolejeunea acutangula (Nees) Grolle & EX & AM, AT, SA & Neotropical & Reis TR 402 \\
\hline "*Cheilolejeunea adnata (Kunze ex Lehm.) Grolle & $\mathrm{CO}$ & AM, AT, SA & Neotropical & Reis TR 385 \\
\hline $\begin{array}{l}\text { "*Cheilolejeunea discoidea (Lehm. \& Lindenb.) } \\
\text { R.M.Schust. \& Kachroo }\end{array}$ & $\mathrm{CO}$ & AT, SA, PL & Neotropical & Reis TR 381 \\
\hline Cheilolejeunea rigidula (Mont.) R.M.Schust. & $\mathrm{CO}$ & $\begin{array}{l}\text { AM, AT, CA, } \\
\text { SA, PL }\end{array}$ & Pantropical & Reis TR 390 \\
\hline $\begin{array}{l}\text { "Cheilolejeunea xanthocarpa (Lehm. \& Lindenb.) } \\
\text { Malombe }\end{array}$ & EX & AT, SA & Pantropical & Reis TR 402 \\
\hline "*Lejeunea aphanes Spruce & $\mathrm{CO}$ & AT, PL & Neotropical & Reis TR 381 \\
\hline Lejeunea flava (Sw.) Nees & RU & $\begin{array}{l}\text { AM, AT, CA, } \\
\text { SA, PA, PL }\end{array}$ & Pantropical & Reis TR 404 \\
\hline Lejeunea laetevirens Nees \& Mont. & $\mathrm{CO}$ & $\begin{array}{l}\text { AM, AT, CA, } \\
\text { SA, PL }\end{array}$ & Neotropical & Reis TR 387 \\
\hline "*Lejeunea oligoclada Spruce & $\mathrm{CO}$ & AT & Endemic to Brazil & Reis TR 410 \\
\hline Marchesinia brachiata (Sw.) Schiffn. & $\mathrm{CO}$ & $\begin{array}{c}\text { AM, AT, CA, } \\
\text { SA }\end{array}$ & Neotropical & Reis TR 410 \\
\hline \multicolumn{5}{|l|}{ Metzgeriaceae Raddi (1/2) } \\
\hline "Metzgeria albinea Spruce & $\mathrm{CO}$ & AT, SA & Neotropical & Reis TR 400 \\
\hline Metzgeria furcata (L.) Dumort. & $\mathrm{CO}$ & $\begin{array}{l}\text { AM, AT, CA, } \\
\text { SA }\end{array}$ & Neotropical & Reis TR 410 \\
\hline
\end{tabular}




\begin{tabular}{|c|c|c|c|c|}
\hline Taxa & Sub. & Domains & World Distribution & Vouchers \\
\hline \multicolumn{5}{|l|}{ Plagiochilaceae (Joerg.) K. Müll. (1/4) } \\
\hline **Plagiochila cristata $(\mathrm{Sw}$.$) Lindenb.$ & $\mathrm{CO}$ & $\mathrm{AM}, \mathrm{AT}$ & Neotropical & Reis TR 400 \\
\hline Plagiochila disticha (Lehm. \& Lindenb.) Lindenb. & $\mathrm{CO}$ & $\begin{array}{l}\text { AM, AT, CA, } \\
\text { SA, PL }\end{array}$ & Neotropical & Reis TR 392 \\
\hline Plagiochila martiana (Nees) Lindenb. & $\mathrm{CO}$ & $\begin{array}{l}\text { AM, AT, CA, } \\
\text { SA, PA }\end{array}$ & Neotropical & Reis TR 410 \\
\hline "*Plagiochila patula $(\mathrm{Sw}$.$) Lindenb.$ & $\mathrm{CO}$ & $\mathrm{AM}, \mathrm{AT}$ & Neotropical & Reis TR 381 \\
\hline \multicolumn{5}{|l|}{ Ricciaceae L. (1/3) } \\
\hline *Riccia albopunctata Jovet-Ast & $\mathrm{TE}$ & $\begin{array}{l}\text { AT, CA, SA, } \\
\text { PL }\end{array}$ & Neotropical & Reis TR 347 \\
\hline "**Riccia subplana Steph. & $\mathrm{TE}$ & AM, PA & Neotropical & Reis TR 314 \\
\hline Riccia vitalii Jovet-Ast & $\mathrm{TE}$ & $\begin{array}{l}\text { AM, AT, CA, } \\
\text { SA, PA, PL }\end{array}$ & Neotropical & Reis TR 294 \\
\hline \multicolumn{5}{|l|}{ Bryophyta } \\
\hline \multicolumn{5}{|l|}{ Brachytheciaceae Schimp. (2/3) } \\
\hline Squamidium leucotrichum (Taylor) Broth. & EX & $\begin{array}{l}\text { AM, AT, CA, } \\
\text { SA }\end{array}$ & Neotropical & Reis TR 402 \\
\hline Squamidium nigricans (Hook.) Broth. & EX & AT, CA & Neotropical & Reis TR 402 \\
\hline Zelometeorium patulum (Hedw.) Manuel & $\mathrm{CO}$ & $\begin{array}{l}\text { AM, AT, CA, } \\
\text { SA, PL }\end{array}$ & Neotropical & Reis TR 410 \\
\hline \multicolumn{5}{|l|}{ Bryaceae Schwägr. (3/4) } \\
\hline $\begin{array}{l}\text { *Brachymenium exile (Dozy \& Molk.) Bosch \& Sande } \\
\text { Lac. }\end{array}$ & $\mathrm{TE}$ & AT, CA, SA & Endemic to Brazil & Reis TR 361 \\
\hline Bryum argenteum Broth. & RU & $\begin{array}{l}\text { AM, AT, CA, } \\
\text { SA, PA }\end{array}$ & Pantropical & Reis TR 404 \\
\hline Bryum coronatum Schwägr. & $\mathrm{TE}$ & $\mathrm{AT}, \mathrm{CA}$ & Pantropical & Reis TR 342 \\
\hline "*Rosulabryum densifolium (Brid.) Ochyra & $\mathrm{TE}$ & AT, SA & Neotropical & Reis TR 409 \\
\hline \multicolumn{5}{|l|}{ Calymperaceae Kindb. (3/3) } \\
\hline Calymperes palisotii Schwägr. & $\mathrm{CO}$ & $\begin{array}{l}\text { AM, AT, CA, } \\
\text { SA }\end{array}$ & Neotropical & Reis TR 381 \\
\hline Octoblepharum albidum Hedw. & $\mathrm{CO}$ & $\begin{array}{l}\text { AM, AT, CA, } \\
\text { SA, PA, PL }\end{array}$ & Pantropical & Reis TR 399 \\
\hline "*Syrrhopodon parasiticus (Sw. ex Brid.) Besch. & $\mathrm{CO}$ & $\begin{array}{l}\text { AM, AT, SA, } \\
\text { PL }\end{array}$ & Pantropical & Reis TR 398 \\
\hline \multicolumn{5}{|l|}{ Cryphaeaceae Schimp. (1/1) } \\
\hline Schoenobryum concavifolium (Griff.) Gangulee & $\mathrm{CO}$ & $\begin{array}{l}\text { AM, AT, CA, } \\
\text { PA, PL, SA }\end{array}$ & Neotropical & Reis TR 400 \\
\hline \multicolumn{5}{|l|}{ Fabroniaceae Schimp. (1/1) } \\
\hline Fabronia ciliaris (Brid.) Brid. & $\mathrm{CO}$ & $\begin{array}{l}\text { AM, AT, CA, } \\
\text { PL }\end{array}$ & $\begin{array}{l}\text { Bolivia, Chile, } \\
\text { Ecuador and } \\
\text { USA }\end{array}$ & Reis TR 387 \\
\hline Fissidentaceae Schimp. (1/2) & & & & \\
\hline
\end{tabular}




\begin{tabular}{|c|c|c|c|c|}
\hline Taxa & Sub. & Domains & World Distribution & Vouchers \\
\hline Fissidens anguste-limbatus Mitt. & $\mathrm{TE}$ & $\begin{array}{l}\text { AM, AT, CA, } \\
\text { SA, PA, PL }\end{array}$ & Neotropical & Reis TR 363 \\
\hline Fissidens hornschuchii Mont. & $\mathrm{TE}$ & $\begin{array}{l}\text { AM, AT, CA, } \\
\text { SA, PA, PL }\end{array}$ & Neotropical & Reis TR 338 \\
\hline *Fissidens perfalcatus Broth. & $\mathrm{CO}$ & AT, SA & Neotropical & Reis TR 381 \\
\hline \multicolumn{5}{|l|}{ Leucobryaceae Schimp. (1/2) } \\
\hline Campylopus pilifer Brid. & RU & $\begin{array}{l}\text { AM, AT, CA, } \\
\text { SA, PA }\end{array}$ & Neotropical & Reis TR 404 \\
\hline Campylopus savannarum (Müll. Hal.) Mitt. & EX & $\begin{array}{l}\text { AM, AT, CA, } \\
\text { SA, PL }\end{array}$ & Pantropical & Reis TR 402 \\
\hline \multicolumn{5}{|l|}{ Meteoriaceae Kindb. (2/2) } \\
\hline Floribundaria flaccida (Mitt.) Broth. & $\mathrm{CO}$ & $\begin{array}{l}\text { AM, AT, CA, } \\
\text { SA, PL }\end{array}$ & Neotropical & Reis TR 406 \\
\hline **Meteorium nigrescens (Sw. ex Hedw.) Dozy \& Molk. & $\mathrm{CO}$ & $\begin{array}{l}\text { AM, AT, SA, } \\
\text { PL }\end{array}$ & $\begin{array}{l}\text { Neotropical and } \\
\text { Africa }\end{array}$ & Reis TR 406 \\
\hline \multicolumn{5}{|l|}{ Orthotrichaceae Arn. (2/2) } \\
\hline **Groutiella tomentosa (Hornsch.) Wijk \& Margad. & $\mathrm{CO}$ & $\mathrm{AM}, \mathrm{AT}, \mathrm{SA}$ & Pantropical & Reis TR 387 \\
\hline "*Schlotheimia jamesonii (Arn.) Brid. & RU & $\begin{array}{c}\text { AM, AT, SA, } \\
\text { PA }\end{array}$ & Neotropical & Reis TR 395 \\
\hline \multicolumn{5}{|l|}{ Pottiaceae Schimp. (4/4) } \\
\hline *Barbula indica (Hook.) Spreng. & RU & $\begin{array}{l}\text { AM, AT, CA, } \\
\text { SA, PL }\end{array}$ & Pantropical & Reis TR 310 \\
\hline Dolotortula mniifolia (Sull.) R.H. Zander & $\mathrm{TE}$ & AT, CA, SA & Neotropical & Reis TR 311 \\
\hline Hyophilla involuta (Hook.) A. Jaeger & RU & $\begin{array}{l}\text { AM, AT, CA, } \\
\text { SA, PA, PL }\end{array}$ & Neotropical & Reis TR 312 \\
\hline "*Weisiopsis bahiensis (Müll. Hal.) Broth. & $\mathrm{RU}$ & SA & Endemic to Brazil & Reis TR 309 \\
\hline \multicolumn{5}{|l|}{ Pterobryaceae Kindb. (1/2) } \\
\hline Orthostichopsis praetermissa W.R. Buck & $\mathrm{CO}$ & $\begin{array}{c}\text { AM, AT, CA, } \\
\text { SA }\end{array}$ & Neotropical & Reis TR 406 \\
\hline Orthostichopsis tortipilis (Müll. Hal.) Broth. & RU & AM, AT, CA & Neotropical & Reis TR 401 \\
\hline \multicolumn{5}{|l|}{ Pylaisiadelphaceae Goffinet \& W.R. Buck (1/1) } \\
\hline Isopterygium tenerum (Sw.) Mitt. & $\mathrm{CO}$ & $\begin{array}{l}\text { AM, AT, CA, } \\
\text { SA, PA, PL }\end{array}$ & Cosmopolitan & Reis TR 394 \\
\hline \multicolumn{5}{|l|}{ Sematophyllaceae Broth. (1/2) } \\
\hline *Sematophyllum adnatum (Michx.) Brid. & $\mathrm{CO}$ & $\begin{array}{l}\text { AM, AT, CA, } \\
\text { SA, PA, PL }\end{array}$ & $\begin{array}{l}\text { Neotropical and } \\
\text { Africa }\end{array}$ & Reis TR 385 \\
\hline Sematophyllum subpinnatum (Brid.) E. Britton & $\mathrm{CO}$ & $\begin{array}{l}\text { AM, AT, CA, } \\
\text { SA, PA, PL }\end{array}$ & Pantropical & Reis TR 398 \\
\hline \multicolumn{5}{|l|}{ Stereophyllaceae W.R. Buck \& Ireland (2/3) } \\
\hline Entodontopsis leucostega (Brid.) W.R. Buck \& Ireland & RU & $\begin{array}{l}\text { AM, AT, CA, } \\
\text { SA, PL }\end{array}$ & Neotropical & Reis TR 367 \\
\hline Eulacophyllum cultelliforme (Sull.) W.R. Buck \& Ireland & $\mathrm{CO}$ & $\begin{array}{l}\text { AM, AT, CA, } \\
\text { SA, PL }\end{array}$ & Neotropical & Reis TR 381 \\
\hline
\end{tabular}


North (AC, AM, AP, PA, RO, RR), Northeast (BA, CE, PE), Southeast (MG, RJ, SP), South (PR, SC).

Ceratolejeunea laetefusca (Austin) R.M.Schust., J. Elisha Mitchell Sci. Soc. 72 (2): 306. 1956.

The illustrations of this species is in Dauphin (2003).

It is characterized by the presence of caducous leaves and frequent reduced lobules. It was found on live bark. This is the first record for the Caatinga Domain and for the state of Ceará. Brazilian geographical distribution: North (AC, AM, PA, RR), Northeast (BA, PE), Midwest (GO), Southeast (ES, MG, RJ, SP).

Cheilolejeunea acutangula (Nees) Grolle, J. Hattori Bot. Lab., 45: 173. 1979.

The illustrations of this species is in Gradstein \& Costa (2003).

It is distinguished by clearly mammillose leaf cells and the presence of 2-5 oil bodies per cell. It was collected on rotting log. This is the first record for the Caatinga Domain and for the state of Ceará. Brazilian geographical distribution: North (AM, PA, RR), Northeast (AL, BA, PE), Southeast (ES, MG, RJ, SP), South (RS, SC).

Cheilolejeunea adnata (Kunze ex Lehm.) Grolle, J. Bryol. 9 (4): 529.1977.

The illustrations of this species is in Grolle (1977).

It is characterized by leaf cells presenting trigones, lobules never reduced and with long apical and curved teeth, caducous leaves, and marginal rizhoids on leaves. It was found on live bark. This is the first record for the Caatinga Domain and for the state of Ceará. Brazilian geographical distribution: North (AM, PA), Northeast (BA, PE), Midwest (MT), South (PR, SC).

Cheilolejeunea discoidea (Lehm. \& Lindenb.) R.M.Schust. \& Kachroo, J. Linn. Soc., Bot. 56 (368): 509. 1961.

The illustrations of this species is in Bastos (2017).

It is distinguished by the small size of the gametophytes (up to $0.65 \mathrm{~mm}$ wide), being one of the smaller species of the genus. The reduced and weakly delimited trigones are also diagnostic characteristics. It was collected on live bark. This is the first record for the Caatinga Domain and for the state of Ceará. Brazilian geographical distribution: North (PA), Northeast (BA, SE), Midwest (DF, GO, MS), Southeast (ES, MG, SP).
Cheilolejeunea xanthocarpa (Lehm. \& Lindenb.) Malombe, Acta Bot. Hung. 51 (3-4): 326, 2009. The illustrations of this species is in Gradstein \& Costa (2003).

The striking features of this species are the leaf lobes with strongly involute margins. It was found growing on rotting $\log$. This is the first occurrence for the Caatinga. Brazilian geographical distribution: Northeast (BA, CE), Southeast (ES, MG, SP).

Lejeunea aphanes Spruce, J. Bot. 19: 36. 1881. The illustrations of this species is in Bastos \& Yano (2004), as L. filipes Spruce.

The diagnostic feature of the species is the underleaf that grows attached to the stem and which is difficult to visualize due to its very thin cell walls which are usually collapsed. It was collected on live bark. This is the first record for the Caatinga Domain and for the state of Ceará. Brazilian geographical distribution: Northeast (BA).

Lejeunea oligoclada Spruce, Bull. Soc. Bot. France 36 (Suppl. Congress Bot. 1889): cxcix. 1889 [1890].

The illustrations of this species is in Bastos \& Yano (2009).

It may be confused with Lejeunea phyllobola; however, the smaller size of the gametophyte and the cells finely papillose in Lejeunea oligoclada distinguishes the two species. It was found on live bark. It is endemic to Brazil and this is the first occurrence for the Caatinga Domain and for the state of Ceará. Brazilian geographical distribution: Northeast (AL, BA, PE), Southeast (ES, MG, RJ, $\mathrm{SP})$, South (PR, SC).

Metzgeriaceae H. Klinggr.

Metzgeria albinea Spruce, Bull. Soc. Bot. France 36: 201. 1889.

The illustrations of this species is in Gradstein \& Costa (2003).

It is characterized by the presence of two rows of cells on both surfaces (dorsal and ventral) of the midrib in transverse section, with about 10-15 medullary cells and two hairs per marginal cell. It was collected on live bark. This is the first record for the Caatinga Domain. Brazilian geographical distribution: Northeast (BA, CE, PE), Midwest (GO), Southeast (ES, MG, RJ, SP), South (PR, RS, SC). 
Plagiochillaceae Müll. Frib. \& Herzog

Plagiochila cristata (Sw.) Lindenb., Sp. Hepat. (fasc.1): 33. 1839.

The illustrations of this species is in Heinrichs (2002).

It is distinguished by leaves that are longer than wider, with 15 to 50 teeth, two long teeth at the apex, and dentate ventral margin. This is the first occurrence for the Caatinga Domain and for the state of Ceará. Brazilian geographical distribution: North (AM, PA), Northeast (BA, RN), Southeast (ES, MG, RJ, SP).

Plagiochila patula (Sw.) Lindenb., Sp. Hepat. (fasc.1): 21. 1839.

The illustrations of this species is in Gradstein \& Costa (2003).

The dichotomous branching pattern, weakly dentate leaves with a high shoulder and with longdecurrent and entire ventral base are diagnostic characteristics of the species. Heinrichs et al. (1998) also mention the presence of a high dorsal wing in the perianth. This is the first record for the Caatinga Domain and for the state of Ceará. Brazilian geographical distribution: North (AC, PA), Northeast (BA, PE), Southeast (MG, RJ, SP), South (PR).

\section{Ricciaceae Rchb.}

Riccia albopunctata Jovet-Ast, Cryptog. Bryol. Lichénol. 12 (3): 237, 1991.

The illustrations of this species is in Jovet-Ast (1991).

It is characterized by the numerous white spots, which are idioblastic cells visible through the epidermis, densely areolated distal spore surface and with tuberculated angles. It was collected on soil. This is the first citation for the state of Ceará. Brazilian geographical distribution: Northeast (BA), Midwest (MS, MT), Southeast (SP), South (PR, RS, SC).

Riccia subplana Steph., Symb. Antill. (Urban) 3 (2): 275, 1902.

The illustrations of this species is in Ayub et al. (2014).

It is characterized by stems $6-7 \mathrm{~mm}$ long, round apex, entire margin, absence of papillae or cilia, and presence of pink scales. It was collected on soil. The species has a disjunct distribution and had been recorded only for the Amazon forest and Rio Grande do Sul in Brazil (Ayub et al. 2014). It was found on soil. This is the first citation for the
Northeast region of Brazil and for the Caatinga Domain. Brazilian geographical distribution: North (AM), South (RS).

\section{Bryophyta}

Bryaceae Schwägr.

Brachymenium exile (Dozy \& Molk.) Bosch \& Sande Lac., Bryol. Jav. 1: 139, 1860.

The illustrations of this species is in Sharp et al. (1994).

It is distinguished by the ligulate-lanceolate leaves, equally arranged in the stem, with acute to acuminate apex, rhomboid-hexagonal cells, entire and bordered margins, and long-excurrent costa ending in a wing tip. It was found on soil. It is endemic to Brazil and this is the first record for the state of Ceará. Brazilian geographical distribution: Northeast (BA, PE), Midwest (GO, MS), Southeast (RJ, SP).

Rosulabryum densifolium (Brid.) Ochyra, Biodivers. Poland 3: 162. 2003.

The illustrations of this species is in Ochyra et al. (2003).

It is characterized by the robust size of the gametophytes, up to $10 \mathrm{~cm}$ long, narrow leaves, $6.5 \mathrm{~mm}$ long, with serrate margins. It was found on soil. This is the first record for the Caatinga Domain and for the state of Ceará. Brazilian geographical distribution: Northeast (BA, PE), Midwest (DF), Southeast (ES, MG, RJ, SP), South (PR, RS, SC).

Calymperaceae Kindb. Syrrhopodon parasiticus (Sw. ex Brid.) Besch., Ann. Sci. Nat., Bot., Ser. 8, 1 (5-6): 298, 1895. The illustrations of this species is in Sharp et al. (1994).

It is characterized by dimorphic leaves with unipapillose cells, filamentous propagules in the median region of the leaf, and cancellinae ending in acute angles. It was collected on live bark. This is the first record for the Caatinga Domain and for the state of Ceará. Brazilian geographical distribution: North (AC, AM, PA, RO, RR), Northeast (BA, PE), Midwest (DF, GO, MS, MT), Southeast (ES, MG, RJ, SP), South (PR, SC).

Fissidentaceae Schimp.

Fissidens perfalcatus Broth., Bih. Kongl. Svenska Vetensk.-Akad. Handl. 26 Afd. 3 (7): 13. 1900. The illustrations of this species is in Sharp et al. (1994). 
It is characterized by oblong-ovate leaves, with vaginant laminae completely covering the stem, usually extending beyond the stem, limbidium occupying all the extension or up to $3 / 4$ of the vaginant lamina in all leaves, and unipapillose cells. It was collected on live bark. This is the first record for the Caatinga Domain and for the state of Ceará. Brazilian geographical distribution: North (TO), Northeast (BA, PB, PE), Midwest (GO, MT), Southeast (ES).

Meteoriaceae Kindb.

Meteorium nigrescens (Sw. ex Hedw.) Dozy \& Molk., Musc. Frond. Ined. Archip. Ind. 5: 160, 1848.

The illustrations of this species is in Buck (1998).

It is distinguished by gametophytes with cylindrical branches and blackish apex, weakly concave and triangular-ovate leaves, with gradually acuminate and never piliferous apex, cordate base, crenulated margin, costa extending up to $1 / 2$ of the leaf, and sub-quadratic and smooth alar cells. It was found on live bark. This is the first record for the Caatinga Domain and for the state of Ceará. Brazilian geographical distribution: North (PA), Northeast (BA, PE), Midwest (DF, GO, MS), Southeast (ES, MG, RJ, SP), South (PR, RS, SC).

Orthotrichaceae Arn.

Groutiella tomentosa (Hornsch.) Wijk \& Margad., Taxon 9 (2): 51, 1960.

The illustrations of this species is in Sharp et al. (1994).

It is characterized by leaves with fragile and brittle apex, and marginal elongated basal cells contrasting with the rounded hexagonal cells of the lamina. It was found on live bark. This is the first record for the Caatinga Domain and for the state of Ceará. Brazilian geographical distribution: North (AM, PA, RO), Northeast (BA, PE, SE), Midwest (MT), Southeast (RJ, SP).

Schlotheimia jamesonii (Arn.) Brid., Bryol. Univ. 1: 742.1826.

The illustrations of this species is in Allen (2002).

It is distinguished by the glossy, green to brown coloration, densely tomentose gametophytes, oblong and smooth leaves with abruptly acuminate apex. It was found on rock. This is a new record for the Caatinga Domain and for the state of Ceará. Brazilian geographical distribution: North (AC), Northeast (BA, MA, PE), Midwest (DF, GO, MS), Southeast (ES, MG, RJ, SP), South (PR, RS, SC).
Pottiaceae Schimp.

Barbula indica (Hook.) Spreng., Nomencl. Bot. 2: 72.1824.

The illustrations of this species is in Sharp et al. (1994)

It is characterized by elliptic ovate leaves with flat or weakly curved margins in the medial portion, presence of masses of green, ovoid propagules, with three or more cells, produced in the axils of the leaves. It was found on rock. This is the first record for the state of Ceará. Brazilian geographical distribution: North (AC, AM, PA), Northeast (BA, PE, RN, SE), Midwest (DF, GO, MS, MT), Southeast (ES, MG, RJ, SP), South (PR, RS).

Weisiopsis bahiensis (Müll. Hal.) Broth., Nat. Pflanzenfam. 10: 271. 1924.

Fig. 2

It is characterized by small gametophytes, tubular leaves with flat to curved margins, flattened guide cells, absent or single peristome. It was found on rock. It is endemic to Brazil and this is the first report for the state of Ceará. Brazilian geographical distribution: Northeast (BA, PI).

Sematophyllaceae Broth.

Sematophyllum adnatum (Michx.) E. Britton, Bryologist 5: 65, 1902.

The illustrations of this species is in Buck (1998).

Gametophytes with erect-patent, ecostate, flat stem leaves, with gradually acuminate apex, weakly inflated and yellow-orange alar cells, quadrate supra alar cells, few in number (2-3), measuring $1 / 2$ of the length of the alar cells. It was collected on live logs. This is the first occurrence for the state of Ceará. Brazilian geographical distribution: North (AM, PA, TO), Northeast (BA, MA, RN), Midwest (DF, GO, MS, MT), Southeast (ES, MG, RJ, SP).

\section{Discussion}

The 59 bryophyte species found in the Apodi Plateau correspond to $30 \%$ of the total number species registered in the state of Ceará. This number can be considered high when compared to other surveys carried out in Caatinga areas, such as those where were conducted the studies by Porto et al. (1994) in Caruaru county, where 17 species were registered, and Porto \& Bezerra (1996), who reported 13 bryophyte species for the municipality of Agrestina, also in Pernambuco.

Among the liverworts, the most representative families were Lejeuneaceae (12 spp.) and Plagiochilaceae (4 spp.). As for mosses, the 
families with the highest number of species were Bryaceae and Pottiaceae (4 spp.). In the present study, it was observed that the majority of the most frequent species have adaptations to thrive in restrictive environmental conditions, such as xeric environments, being considered generalists or typically adapted to solar incidence, such as Frullania caulisequa (Nees) Nees, Riccia vitallii Jovet-Ast, Bryum argenteum Broth., Octoblepharum albidum Hedw., Campylopus savannarum (Müll. Hal.) Mitt. and Hyophilla involuta (Hook.) A. Jaeger (Ochi 1980; Frahm 1991; Gradstein et al. 2001). As regards the family Lejeuneaceae, this is one of the largest families of liverworts and, although better represented in humid forests, they occur also quite frequently in open and xeric environments (Gradstein 1994;
Gradstein et al. 2001). The Lejeuneaceae species recorded in this study present a considerable wide tolerance or are pioneers. In Brazil, they have also been found in disturbed forests, savannas, sandbanks, Caatinga and even plantations and pastures (Gradstein \& Costa 2003; Forzza et al. 2010).

The results of this study reinforce the importance of the Apodi Plateau for the preservation of bryophyte species in Caatinga areas and for the recognition of hot spots in order to guide conservation efforts to areas with high diversity of species and endemism (Kier et al. 2009). According to Costa \& Peralta (2015), Brazil has 242 endemic bryophyte species, of which only one is cited for the state of Ceará. The present study report three new records of endemic Brazilian species for the state

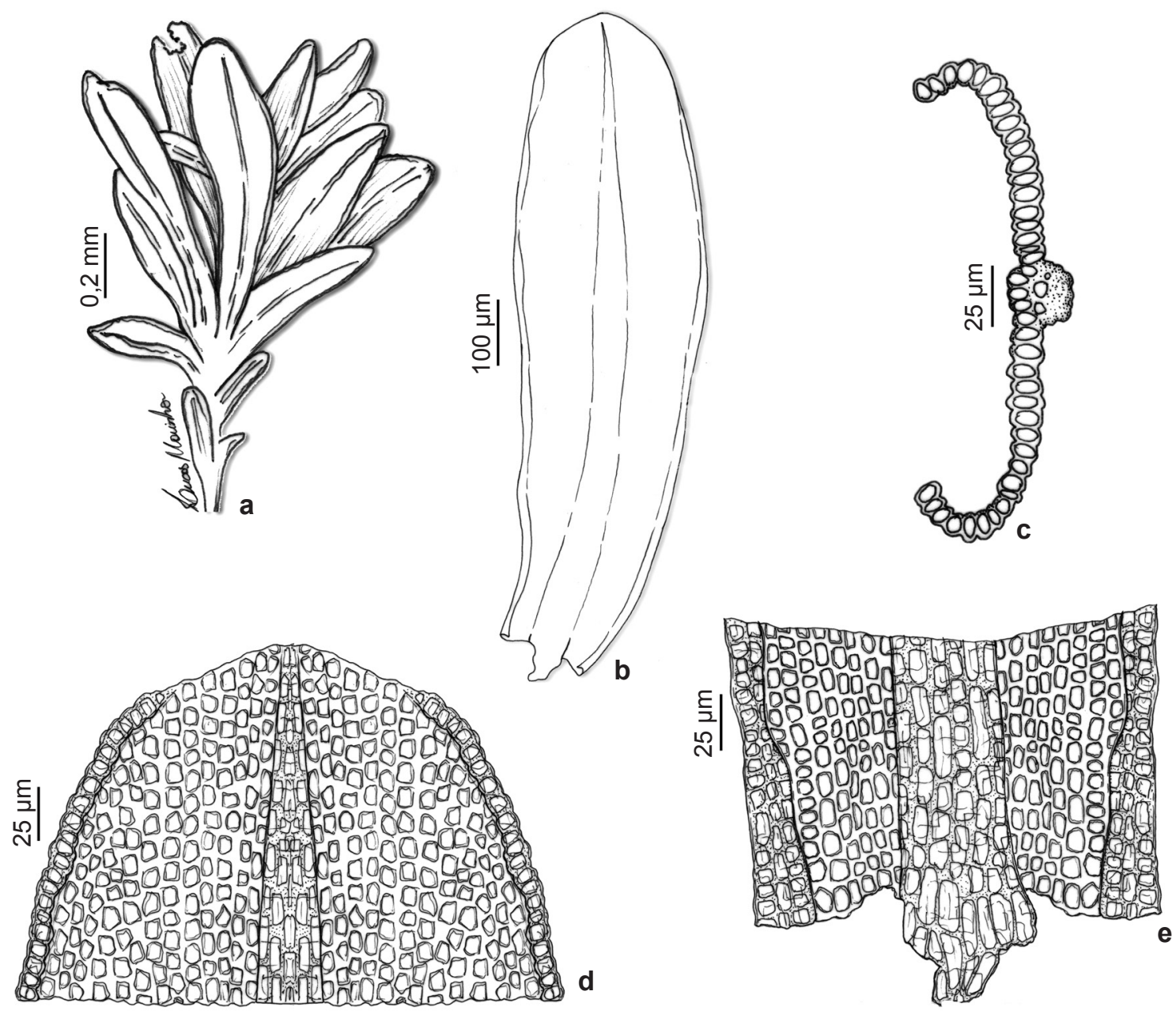

Figure 2 - a-e. Weisiopsis bahiensis - a. gametophyte; b. leaf; c. cross section of the leaf; d. leaf apex; e. basal portion of the leaf. 
of Ceará: Weisiopsis bahiensis (Müll. Hal.) Broth., Lejeunea oligoclada Spruce and Brachymenium exile (Dozy \& Molk.) Bosch \& Sande Lac., the first two are also new records for the Caatinga Domain.

Weisiopsis bahiensis seems to have some inconsistencies in the information available in literature. According to the original work (Müller 1855, as Pottia bahiensis Müll. Hal.) The species type is from the state of Bahia, however, at the BFG (2018) platform, it is cited only for the state of Piauí, which is probably wrong. Yano et al. (2009) cited W. bahiensis from Oeiras, Goiás state, although Oeiras is actually located in Piauí state. Crosby et al. (1999) ranked it as a species for which no new information could be found in the post-1962 literature, however, Gradstein et al. (2001) considered this species as valid. Costa (2016) is the most recent citation of this species in Brazil, however, as well as Yano et al. (2009), with herbarium samples collected in 1978. Therefore, this work represents a rediscovery of $W$. bahiensis in nature and the third record in Brazil and in the world.

The high number of new species reported for the state of Ceará and for the Caatinga Domain underscores the importance of continuous floristic surveys, especially in areas to which there is a gap of knowledge such as the Apodi Plateau, part of the Caatinga Domain in the Semiarid region of Brazil.

\section{Acknowledgements}

The authors thank the Program for Research in the Biodiversity of the Semiarid region of Brazil (PPBio/CNPq) for the support in the field work and Thamara Rodrigues dos Reis for the collection of the samples.

\section{References}

Ab’Sáber AN (1974) O domínio morfoclimático semi-árido das caatingas brasileiras. Série Geomorfologia. Vol. 43. Instituto de Geografia/ USP, São Paulo. Pp. 1-39.

Allen BH (2002) Moss flora of Central America, Part 2. Encalyptaceae-Orthotrichaceae. Monographs in Systematic Botany from the Missouri Botanical Garden: 1-699.

Andrade-Lima D (1981) The caatingas dominium. Revista Brasileira de Botânica 4: 149-163.

Araújo Filho JA \& Carvalho FC (1997) Desenvolvimento sustentado da caatinga. Embrapa-CNPC Circular Técnica, 13. Embrapa-CNPC, Sobral. 19p.

Ayub DM, Costa DP \& Santos RP (2014) Additions to the Ricciaceae flora of Rio Grande do Sul, including two remarkable records for the Brazilian liverwort flora. Phytotaxa 161: 294-300.

Bastos CJP (2017) The genus Cheilolejeunea (Spruce) Steph. (Lejeuneaceae, Marchantiophyta) in the Americas. Pesquisas. Botânica 70: 5-78.

Bastos CJP \& Yano O (2004) New records of Lejeuneaceae (Marchantiophyta) for the Brazil. Acta Botanica Malacitana 29: 13-21.

Bastos CJP \& Yano O (2009) O gênero Lejeunea (Lejeuneaceae) no estado da Bahia, Brasil. Hoehnea 36: 303-320.

BFG - The Brazil Flora Group (2018) Brazilian Flora 2020: innovation and collaboration to meet Target 1 of the Global Strategy for Plant Conservation (GSPC). Rodriguésia 69: 1513-1527.

Bordin J \& Yano O (2013) Fissidentaceae (Bryophyta) do Brasil. Boletim do Instituto de Botânica 22: 1-168.

Brito AERM \& Pôrto KC (2000) Guia de estudos de briófitas: briófitas do Ceará. Edições UFC: 1-66.

Buck WR (1998) Pleurocarpous mosses of the West Indies. Memoirs of The New York Botanical Garden 82: 1-400.

Castelletti CHM, Silva JMC, Tabarelli M \& Santos AMM (2004) Quanto ainda resta da Caatinga? Uma estimativa preliminar. In: Silva JMC, Tabarelli M \& Fonseca MT (orgs.) Biodiversidade da Caatinga: áreas e ações prioritárias para a conservação. Ministério do Meio Ambiente, Brasília. 440p.

Costa DP (2016) A synopsis of the family Pottiaceae in Brazil. Phytotaxa 251: 1-69.

Costa DP \& Peralta DF (2015) Bryophytes diversity in Brazil. Rodriguésia 66: 1063-1071.

Crandall-Stotler B, Stotler RE \& Long DG (2009) Phylogeny and classification of the Marchantiophyta. Edinburgh Journal of Botany 66: 155-198.

Crosby MR, Magill RE, Allen B \& He S (1999) A checklist of the mosses. Missouri Botanical Garden, St. Louis. 325p.

Dauphin G (2003) Ceratolejeunea. Flora Neotropica Monograph 90: 1-86.

Fernandes AG (1990) Temas fisiográficos. Stylos Comunicações, Fortaleza. 116p.

Ferri MG (1980) Vegetação brasileira. Editora Itatiaia/ EDUSP, São Paulo. 157p.

Filho PT, Silva JAA, Meunier IMJ \& Ferreira RLC (2001) Fisionomias da cobertura vegetal da Floresta Nacional do Araripe, estado do Ceará. Brasil Florestal 20: 13-21.

Forzza RC, Leitman PM, Costa AF, Carvalho Jr. AA, Peixoto AL, Walter BMT, Bicudo C, Zappi D, Costa DP, Lleras E, Martinelli G, Lima HC, Prado J, Stehmann JR, Baumgratz JFA, Pirani JR, Sylvestre L, Maia LC, Lohmann LG, Queiroz LP, Silveira M, Coelho MN, Mamede MC, Bastos MNC, Morim MP, Barbosa MR, Menezes M, Hopkins M, Secco R, Cavalcanti TB \& Souza VC (2010) Catálogo 
de plantas e fungos do Brasil. 2 vols. Andrea Jakobsson Estúdio, Instituto de Pesquisas Jardim Botânico do Rio de Janeiro, Rio de Janeiro. 1699p.

Frahm JP (1991) Dicranaceae: Campylopodioideae, Paraleucobryoideae. Flora Neotropica, monograph 54: $1-237$.

Frahm JP (2003) Manual of tropical bryology. Tropical Bryology 23: 1-196.

Giulietti AM, Neta ALB, Castro AAJF, Gamarra-Rojas CFL, Sampaio EVSB, Virgínio JF, Queiroz LP, Figueiredo MA, Rodal MJN, Barbosa MRV \& Harley RM (2004) Diagnóstico da vegetação nativa do bioma Caatinga. In: Silva JMC, Tabarelli M \& Fonseca MT (orgs.) Biodiversidade da Caatinga: áreas e ações prioritárias para a conservação. Ministério do Meio Ambiente, Brasília. Pp. 1-44.

Goffinet B, Buck WR \& Shaw AJ (2009) Morphology and classification of the bryophyta. In: Goffinet B \& Shaw AJ (eds.) Bryophyte biology, Cambridge University Press. 2: 55-138.

Gradstein SR (1994) Lejeuneaceae: Ptychantheae, Brachiolejeuneae. Flora Neotropica 61: 1-216.

Gradstein SR \& Costa DP (2003) The Hepaticae and Anthocerotae of Brazil. Memoirs of The New York Botanical Garden 87: 1-301.

Gradstein SR, Churchill SP \& Salazar Allen N (2001) Guide to the bryophytes of tropical America. Memoirs of the New York Botanical Garden 86: $1-585$.

Grolle R (1977) Miscellanea hepaticologica. Journal of Bryology 9: 529-538.

Heinrichs J (2002) A taxonomic revision of Plagiochila sect. Hylacoetes, sect. Adiantoidea and sect. Fuscoluteae in the Neotropics with a preliminary subdivision of neotropical Plagiochilaceae into nine lineages. Bryophytorum Bibliotheca 58: 1-184.

Heinrichs J, Gradstein SR \& Grolle R (1998) A revision of the neotropical species of Plagiochila (Dumort.) Dumort. (Hepaticae) described by Olof Swartz. The Journal of the Hattori Botanical Laboratory 85: 1-32.

Jovet-Ast S (1991) Riccia (Hépatiques, Marchantiales) d'Amérique Latine. Taxons du Sous-Genre Riccia. Cryptogamie, Bryologie Lichénologie 12: 189-370.

Kier G, Kreft H, Lee TM, Jetz W, Ibisch P, Nowicki C, Mutke J \& Barthlott W (2009) A global assessment of endemism and species richness across island and mainland regions. Proceedings of the National Academy of Sciences 106: 9322-9327.

Lemos-Michel E (2001) Hepáticas epífitas sobre o pinheiro-brasileiro no Rio Grande do Sul. Editora da Universidade Federal do Rio Grande do Sul, Porto Alegre. 191p.

Luetzelburg PV (1974) Estudo botânico do Nordeste. (IFCS, Série I.A. Publicação, 57, v. 3.). Inspetoria federal de obras contra as secas, Rio de Janeiro. $283 p$.

MMA - Ministério do Meio Ambiente (2004) Biodiversidade da caatinga: áreas e ações prioritárias para a conservação. Ministério do Meio Ambiente, Universidade Federal de Pernambuco, Brasília. 382p.

MMA - Ministério do Meio Ambiente (2010) Monitoramento dos biomas brasileiros: bioma Caatinga. MMA, Brasília. 46p.

Müller C (1855) De muscis novis, incomplete descripts, neglectis criticisve. Botanische Zetuing 13: 764.

Nimer E (1989) Climatologia do Brasil. 2a ed. IBGESUPREN (Fundação IBGE-SUPREN, Recursos Naturais e Meio Ambiente), Rio de Janeiro. 421p.

Ochi H (1980) A revision of the Neotropical Bryoideae, Musci. First Part. The Journal of the Faculty of Education Tottori University, Natural Science 29: 49-154.

Ochyra R, Żarnowiec J \& Bednarek-Ochyra H (2003) Census catalogue of Polish mosses. Biodiversity of Poland 3: 1-372.

Oliveira HC \& Alves MH (2007) Adições à brioflora do estado do Ceará, Brasil. Rodriguésia 58: 1-11.

Oliveira HC \& Bastos CJP (2009) Jungermanniales (Marchantiophyta) da Chapada da Ibiapaba, Ceará, Brasil. Acta Botanica Brasílica 23: 1202-1209.

Oliveira HC \& Bastos CJP (2010a) Musgos pleurocárpicos da Chapada da Ibiapaba, Ceará, Brasil. Acta Botanica Brasílica 24: 193-204.

Oliveira HC \& Bastos CJP (2010b) Fissidentaceae (Bryophyta) da Chapada da Ibiapaba, Ceará, Brasil. Revista Brasileira de Botânica 33: 393-405.

Pôrto KC, Silveira MFG \& Sá PSA (1994) Briófitas de Caatinga. Vol. 1. Estação experimental do IPA. Caruaru, PE. Acta Botanica Brasílica 8: 77-85.

Pôrto KC \& Bezerra MFA (1996) Briófitas de Caatinga. Vol. 2. Agrestina, Pernambuco, Brasil. Acta Botanica Brasílica 10: 93-102.

Rizzini CT (1997) Tratado de fitogeografia do Brasil. 2a ed. Âmbito Cultural, Rio de Janeiro. 747p.

Romariz DA (1974) Aspectos da vegetação do Brasil. IBGE, Rio de Janeiro. 126p.

Sampaio EVSB (1995) Overview of the Brazilian caatinga. In: Bullock SH, Mooney HA \& Medina E (eds.) Seasonally dry tropical forests. University Press, Cambridge. Pp. 35-63.

Sharp AJ, Crum H \& Eckel PM (1994) The moss flora of Mexico. Memoirs of The New York Botanical Garden 69: 1- 1113.

Siqueira SMC, Costa PS, Souza EB \& Oliveira HC (2011) Briófitas de um remanescente de Mata Atlântica no Município de Ubajara, CE, Brasil. Hoehnea 38: 597-608.

Yano O \& Peralta DF (2007) Musgos (Bryophyta). 
In: Rizzo JA (coord.) Flora dos estados de Goiás e Tocantins: criptógamos. Vol. 6. Universidade Federal de Goiás, Goiânia. Pp. 1-333.

Yano O \& Pôrto KC (2006) Diversidade das briófitas das matas serranas do Ceará, Brasil. Hoehnea 33: $7-40$.
Yano O, Bordin J \& Peralta DF (2009) Briófitas dos estados do Ceará, Maranhão, Paraíba, Piauí e Rio Grande do Norte (Brasil). Hoehnea 36: 387-415.

Zander RH (1993) Genera of the Pottiaceae: mosses of harsh enviroments. Bulletin of the Buffalo Society of Natural Sciences 32: 1-378. 